\title{
Disaster Risk Reduction in Cameroon: Are Contemporary Disaster Management Frameworks Accommodating the Sendai Framework Agenda 2030?
}

\author{
Henry Ngenyam Bang ${ }^{1} \cdot$ Lee Stuart Miles $^{1} \cdot$ Richard Duncan Gordon $^{1}$
}

Published online: 1 October 2019

(C) The Author(s) 2019

\begin{abstract}
Many African countries are prone to numerous hazardous events, exacerbated by the vulnerability of their rapidly increasing population and leading to frequent disasters that often have dire fiscal and development implications. Yet, there is declining sensitivity to these risks, contrary to the conventional wisdom of disaster management (DM) principles. The primary aim of this research is to understand the constraints and/or challenges limiting the ability of contemporary African DM systems/institutional frameworks from implementing adequate disaster risk reduction (DRR) measures. Using a qualitative, case study based research strategy, this research investigates resistance to the effective implementation of DM/DRR within Cameroon's contemporary DM system by using the Sendai Framework for Disaster Risk Reduction 2015-2030 guiding principles for DRR as benchmark. The findings reveal the existence of resistance factors that particularly complicate the communication, decision making, and coordination of DRR activities, the provision of resources, aspects of international assistance, as well as DRR planning and policies. The authors argue that such resistance factors contribute to making Cameroon's DM system more reactive and further undermine risk reduction. The article concludes by offering key recommendations that have the potential to alleviate the identified resistance factors as well as strengthen Cameroon's DM, particularly in relation to capacity building, training, research development, and organizational resilience.
\end{abstract}

Henry Ngenyam Bang

hbang@bournemouth.ac.uk

1 Disaster Management Centre, Bournemouth University, Dorset, Talbot Campus, Fern Barrow, Poole BH12 5BB, UK
Keywords Cameroon · Communication resistance - Disaster management - Disaster management system $\cdot$ Disaster risk reduction $\cdot$ West Africa

\section{Introduction}

The high incidence and frequency of hazards, emergencies, crises, and disasters often threatens the economic and sustainable development of many African countries. Yet, the response to these risks is unsatisfactory and is not in accordance with standard operational disaster management (DM) practices (Myers 2011; Becker et al. 2013; Bang 2014; Adelekan and Asiyanbi 2016; Fraser et al. 2017). These challenges exist in Cameroon where evidence of declining sensitivity to environmental risks abound (Bang et al. 2018, 2019).

To curb hazards/disaster risks in Cameroon (Table 1), the government participates in several regional and international DM frameworks albeit with limited success (Bang et al. 2016; Ashu and Van Nierkerk 2019). One explanatory hypothesis for this situation-advocated in this article-is that the operational DM system in Cameroon is not in conformity with international/conventional DM frameworks. Indeed, the hypothesis is informed by contemporary findings indicating that operational DM systems in many African countries are more reactive than proactive (see Sect. 3).

Although contemporary research on the DM systems of many African countries clearly reveals common operational challenges, the application of theoretical benchmarking that can aid the diagnosis of the problems has often been disregarded or underutilized (Ashu and Van Nierkerk 2019). As Fraser et al. (2017) note, many African countries have adopted a progressive, dynamic, and generic 
Table 1 Different hazard groups/types in Cameroon with some examples from 1980 to 2019

\begin{tabular}{|c|c|c|}
\hline Hazard group & Hazard type & Examples \\
\hline \multirow[t]{2}{*}{ Natural } & \multirow[t]{2}{*}{ Geological } & Volcanic eruptions-Mount Cameroon $(1982,1999,2000,2012)$ \\
\hline & & Gas emissions from crater Lakes_Lake Monoum (1984); Lake Nyos (1986) \\
\hline \multirow[t]{6}{*}{ Potentially socionatural } & Meteorological & $\begin{array}{l}\text { Regular tornadoes, thunderstorms and lightning strikes in South, Far North, Adamawa, and North } \\
\text { Regions }\end{array}$ \\
\hline & \multirow[t]{2}{*}{ Hydrological } & $\begin{array}{l}\text { Flash floods-Kribi (1998); North Region (2008, 2014); Far North (1994, 1996, 1997, 1998, } 1999 \\
\text { 2000, 2005, 2006, 2007, 2010, 2012, 2013, 2014); Douala (August 2000, June 2015); Limbe } \\
\text { (2001, July 2013); Yaounde (April 2008); Bakassi Peninsula (2014); Bamenda (marshy areas of } \\
\text { Mulang, below Foncha and Ntasin, August 2014) }\end{array}$ \\
\hline & & $\begin{array}{l}\text { Landslides-South West (Bafaka Balue, 1997; Wabane, August 2013); Center (Yaounde, 1998); } \\
\text { Bamboutous (June 2003); Bonduma neighborhood, Buea (August 2006); Kekem (October 2007) } \\
\text { Bamenda Escarpment (August 2009); Tombel-Bangem highway (August 2015) }\end{array}$ \\
\hline & \multirow[t]{3}{*}{ Biological } & $\begin{array}{l}\text { Elephant-caused destruction-Far North (Diamare, 1996, 1998, 1999; elephants from Kalfou } \\
\text { Wildlife Park 2014) }\end{array}$ \\
\hline & & $\begin{array}{l}\text { Famine, drought, and locust invasion-Far North (1998-1999-2001) with loss of } 140 \text { tons of cereals } \\
\text { per year; Maroua (2011) }\end{array}$ \\
\hline & & $\begin{array}{l}\text { Epidemics-Cholera (North and Far North, 1996, 1998, 1999, 2010, 2011, 2014; Douala, 2004, } \\
\text { 2005, 2011); Meningitis (Far North, 1998); Red diarrhoea (East, 1997; Messock, 1998; Mbalmayo } \\
\text { 1999; Menchum Division, 2010; Far North, 2011); Measles (Maroua, 2008-2009); Malaria } \\
\text { (Northern Regions, 2013-more than 12,000 victims) }\end{array}$ \\
\hline \multirow[t]{5}{*}{ Technological } & Fires & $\begin{array}{l}\text { Fire incidents-Nsam (1998); Bafoussam market (1999); Mokolo market (1998); Limbe market } \\
\text { (2000); Sangmelima market (1998); Essos market, Yaoundé military headquarters ammunition } \\
\text { depot (2001); Kumba market (2005, 2009); Tiko market (2010); Mboppi market, Douala (2011) } \\
\text { Congo market, Douala (2012); Kumba Hospital (2019); SONARA Oil Refinery (2019) }\end{array}$ \\
\hline & Industrial & Gas-Nsimalen (1996) \\
\hline & \multirow[t]{3}{*}{ Transportation } & Road crashes-Average of 1000 per year \\
\hline & & 3 Plane crashes-Cameroon Airlines $(1984,1995)$; Kenya Airways (2007) \\
\hline & & $\begin{array}{l}\text { Train crashes-271 derailments in 1998; } 5 \text { crashes from October 2016-December } 2017 \text { (October } \\
2016 \text { in Eseka, November } 2016 \text { in Ndokoti, March } 2017 \text { in Elig-Edzoa, July } 2017 \text { in Makondo, } \\
\text { December } 2017 \text { in Maboni) }\end{array}$ \\
\hline \multirow{7}{*}{$\begin{array}{l}\text { Social and } \\
\text { anthropogenic } \\
\text { hazards }\end{array}$} & \multirow[t]{4}{*}{ Crowd-related } & Riots due to civil service salary slashed by $65 \%$ (1993) \\
\hline & & Riots caused by fuel/food price hikes (February 2008, July 2014) \\
\hline & & Civil unrest rallies by opposition parties (1992-1994) \\
\hline & & $\begin{array}{l}\text { Mass demonstrations in the Anglophone region following the unilateral declaration of independence } \\
\text { by the Interim Government of Ambazonia (October 2017) }\end{array}$ \\
\hline & \multirow[t]{2}{*}{ Armed conflict } & Bakassi peninsular crisis-the $1990 \mathrm{~s}$ \\
\hline & & The Anglophone crises turned into an armed conflict-From 2017 and ongoing \\
\hline & $\begin{array}{l}\text { Terrorist } \\
\text { activity }\end{array}$ & Boko Haram insurgency in northern Cameroon—From 2014 and ongoing \\
\hline
\end{tabular}

Source Adapted from Bang (2016, p. 111)

agenda for disaster risk reduction (DRR), but its implementation leaves much to be desired. The main aim of this research is to diagnose factors that pose obstacles and constraints (resistance factors) upon resilience and act as a hindrance to operational DRR in many African countries.

This article perceives the aim of DRR as "preventing new and reducing existing disaster risk and managing residual risk, all of which contribute to strengthening resilience and therefore to the achievement of sustainable development" (UNISDR 2017, p. 16). In theory at least, DRR activities-as enshrined in the Sendai Framework for
Disaster Risk Reduction 2015-2030 (SFDRR) working document (UNISDR 2015a, p. 13-14; see Fig. 1)—can significantly improve DRM.

Importantly, resistance is not simply restricted to aspects that "actively" oppose (openly or covertly) the authority, conduct, and implementation of DM activities, which are often associated with noncompatibility or noncompliance. It also includes aspects that simply foster inertia in DM activities through neglect, incapacity, or even incompetence. Such resistance can be interpreted as representing an issue, area, or location, be it human, virtual, or physical, 


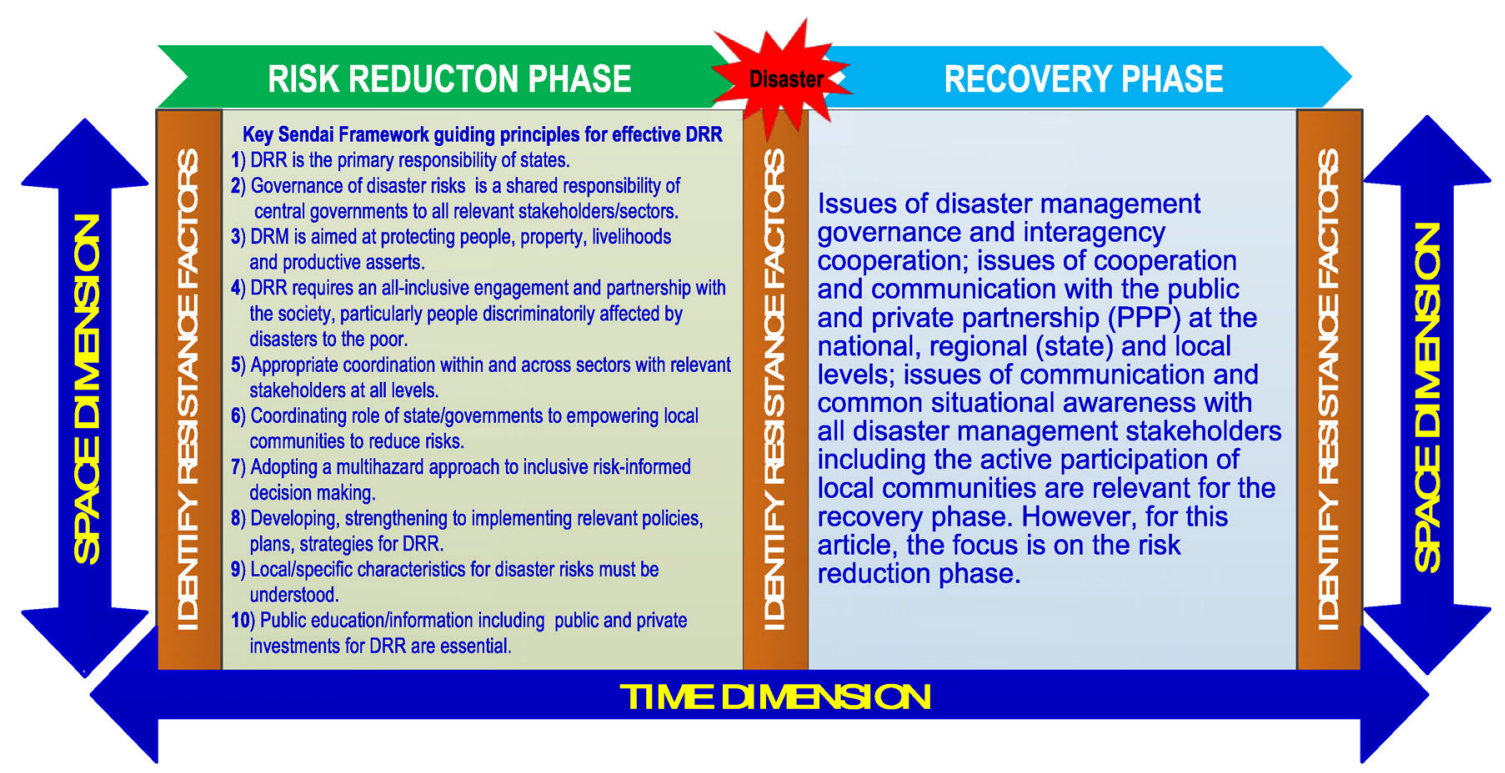

Fig. 1 The existence of resistance factors between risk reduction and recovery components of disaster management (DM)

where resistance can be identified and represents a major challenge that interrupts or undermines the effectiveness of operational DRR and consequently, the entire DM system. Conceptually, resistance factors can also exist in all the key DM activities (Fig. 1).

Figure 1 shows the existence of resistance factors between two main DM components. The framework blends contemporary DRR strategies and best practices as proffered by the SFDRR. As shown on the diagram, the guiding principles operate across different aspects of DM (space dimension) and influence various stages of the DM (time dimension). Resistance factors prevent the smooth operation of these principles to enable effective DRR. Across the space and time of DM, resistance factors prevent the smooth operation of these principles to enable effective DRR. To prevent resistance, a key objective of this research is to understand where and why they exist, or the reason for low resilience to DRR.

\section{Brief Review of Disaster Risk Reduction and Resistance in Cameroon}

Literature on disaster risks in Cameroon suggests challenges in operational DRR are ever present and there is evidence of increasing disaster risk that is not matched by adequate DRR measures. For instance, although the legislative framework for DM has been reviewed several times since independence, "the various ordinances and acts do not provide a framework that demonstrates a clear linkage between disaster mitigation and development planning in the country" (Bang 2014, p. 565). The
Directorate of Civil Protection (DCP) in the Ministry of Territorial Administration is the central agency responsible for organizing and coordinating DM activities, including all institutional structures concerned with DM in Cameroon (MTAD/DCP 2009). The main stakeholder national and international agencies that collaborate with the DCP include government ministries, international organizations, municipalities, civil society, and nongovernmental organizations (NGOs) (Fig. 2). Although government ministries are key players in Cameroon's DRR landscape, they have not developed their own DM frameworks, thereby limiting their scope to engage fully with risk reduction activities and interact with other DRR stakeholders (Bang 2014; Ashu and Van Nierkerk 2019).

Generally, Cameroon's organizational resilience to disasters is weak and the DM system lays more emphasis on disaster response than on risk prevention and mitigation. Where the government DM strategy has shown a leaning towards some disaster preparedness efforts, they have remained theoretical rather than practical (Bang et al. 2014, 2019). For instance, although Law No. 86/016 of $1986,{ }^{1}$ adopted to reorganize civil protection, provided for the creation of a national observatory for disasters, with local branches established to permanently monitor disaster-prone areas. This organ has not yet been established more than three decades after this law was enacted. In addition, DM suffers from inadequate financial support due to the low priority accorded to risk reduction in Cameroon's national budget (Bang 2014, 2016).

\footnotetext{
${ }^{1}$ Law No. 86/016 of 6 December 1986 on the general reorganization of civil protection in Cameroon (French). https://www.camerlex.com/ la-protection-civile-2225/. Accessed 8 January 2019.
} 
Fig. 2 Cameroon's disaster management institutional framework and agreements Source Adapted from Bang (2014, p. 581). DM Disaster management, DRR disaster risk reduction, $I M F$ international monetary fund, $N G O$ Nongovernmental Organization, UNHCF United Nations High Commission for Refugees, UNICEF United Nations Children's Fund, UNDP United Nations Development Programme, $W B$ World Bank, WHO World Health Organization

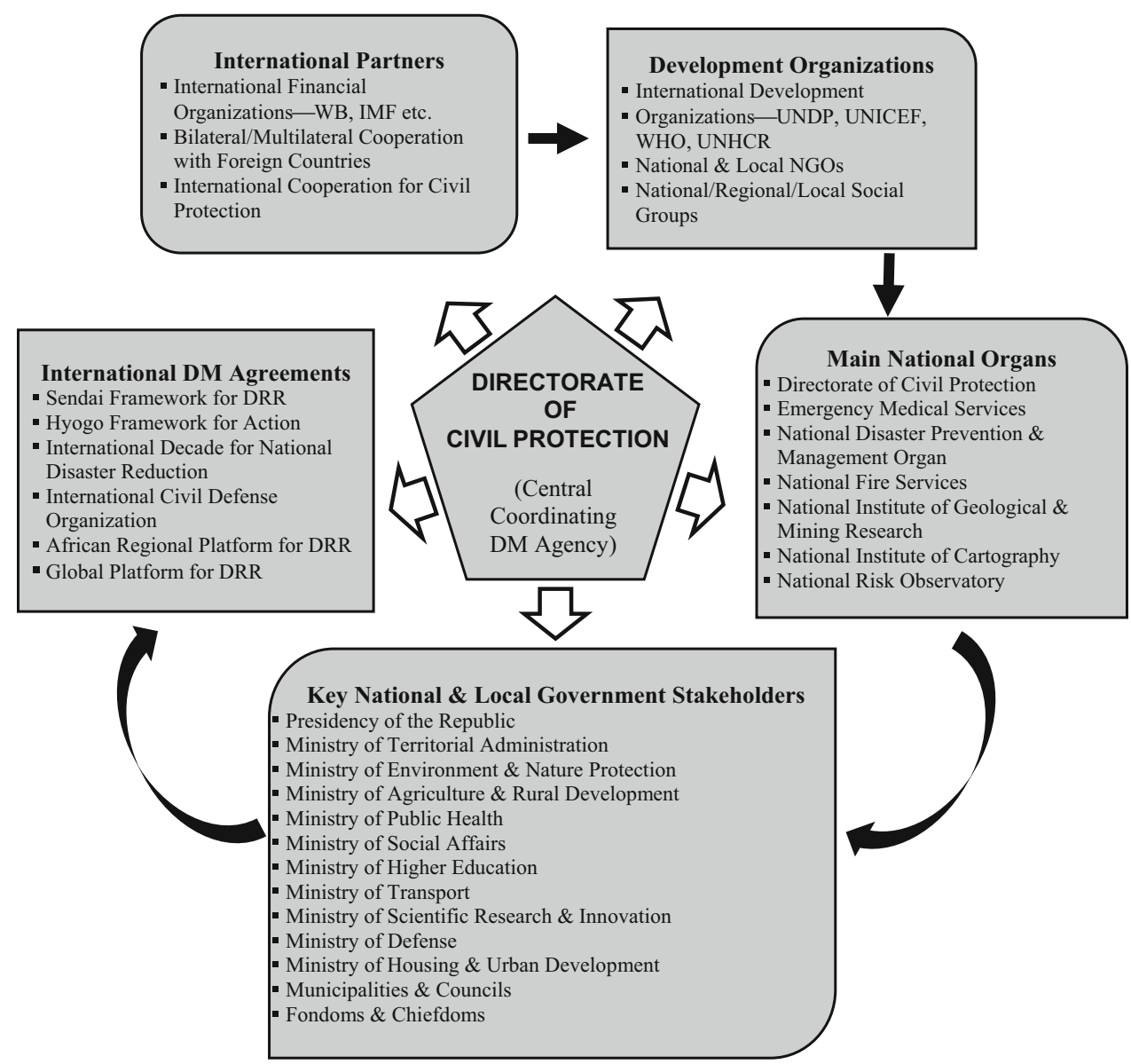

So far then, it can be deduced that most contemporary DM institutional frameworks in the African continent have not implemented adequate DRR measures. Often common barriers are observed and cited in existing literature, notably: (1) low priority given to risk reduction in national budgets; (2) poor information dissemination and knowledge management; (3) failure to prioritize emergency response, creating poor risk governance, DRR unintegrated into national plans, and the absence of a standard DRR budget monitoring system (UNISDR 2013, 2015a, b; World Bank 2018; Ashu and Van Nierkerk 2019).

Moreover, a growing body of literature has begun to chart gaps in the relationship between climate change-induced hazards and urban risk-reduction measures in many African countries-including capacity and resources challenges that many DM systems and authorities face as urbanization increases in the continent. This has created blockages (resistance) to building up resilience in urban centers, posing challenges for climate change adaptation, public health resilience, and DRR in many growing African cities (Adelekan et al. 2015; Johnson 2015). As underlined by SFDRR, resilience is therefore a necessary imperative for Africa to develop. Indeed, the fast rate of urbanization in the region brings scope for enabling development processes that can build resilience and mitigate risks.

\section{Methodology}

The conventional DM/DRR model, as highlighted earlier, has limitations in its implementation in many African countries. Indeed, priorities 1-3 of the SFDRR 2015-2030 lays emphasis on: (1) understanding disaster risk; (2) strengthening disaster risk governance to manage disaster risk; and (3) investing in DRR for resilience (UNISDR 2015a, p. 14; also see Fig. 1 for DRR guidelines). Although laudable, implementation in Africa leaves much to be desired as the brief review in Sect. 3 shows. A notable inquiry for this article, therefore, is to identify and evaluate resistance factors in space and time (Fig. 1) that cause challenges to DRR.

The choice of Cameroon as a case study is relevant to this research because the country's hazard profile is increasing, especially within social and anthropogenic hazards (Table 1). For instance, in 2019, Cameroon's anglophone crisis (involving insurgency in Cameroon's two English speaking North West and South West Regions) 
has caused the displacement of 437,000 people from the affected region by 30 November 2018, with many becoming refugees in neighboring Nigeria (UNHCR 2019). The northern part of the country also hosts more than 350,000 refugees and asylum seekers either fleeing the Boko Haram insurgency in Nigeria, or conflict in the adjacent Central African Republic.

Consequently, this article is based on and presents interpretivist, exploratory, and inductive research that investigated resistance to DRR using the case study of Cameroon. The aim is to aid better understanding of resistance factors influencing Cameroon's DM frameworks and proffer solutions on how to assimilate, accommodate, reduce, and overcome the respective resistance factors. The project had two main phases. The first (research) phase adopted a qualitative methodology for empirical/primary data collection in Cameroon. Primary empirical data were obtained from various sources-technical reports, official documents, and open, semistructured interviews (Bhattacherjee 2012).

Initially, the research pursued a purposive sampling criterion (Etikan et al. 2016) and identified 18 interviewees within Cameroon's DM system (Agencies and Ministries) directly involved with DM/DRR policy formulation and implementation, administration/governance, and the coordination of emergency management activities. Sampling criteria focused on interviewing very experienced DM technocrats $(15+$ years of service in the DM field) who held strategic DM/DRR related functions at the national and regional levels and who could provide rich data on the main research themes. During the data collection process in 2017, 10 top/senior and mid-ranking technocrats (selected from the 18) were interviewed who met the respective sampling criteria. Since Cameroon is bilingual (English and French), the interviews were conducted in the preferred language of the respondent. Interpreters were not needed because the researcher could understand both languages. The interviews took 40-65 min to conduct and covered the depth and breadth of the inquiry because the respondents engaged passionately in the dialogue and explored similar DM themes due to the semistructured nature of the discussion (Cresswell and Plano Clark 2011). As a result, the interviews generated data that are beyond the scope of this article.

The SFDRR priority actions and guiding principles for DRR (Fig. 1) were used as a benchmark to assess resistance to DRR in Cameroon. The key interview themes centered on aspects of DM governance, intersectorial stakeholder cooperation, integration of the DM system, resource allocation and capacity for DRR, DRR education, and crisis communication of vital information. Secondary sources of information were acquired from documented experiences of Cameroon's institutional capability for risk reduction, management of crises and disaster events, academic journals, books, policy documents, and reports on DM/DRR and related themes. Status reports of Cameroon's DCP were invaluable as a resource. International DM agreements, conference proceedings, declarations and speeches, including the documentation of DM stakeholder ministries, were also reviewed to have insight into DRR in Cameroon.

The second phase (field research validation) involved an executive briefing involving senior emergency managers from Cameroon. The briefing served as a peer-review and bench learning exercise where preliminary findings on the research were presented, analyzed, and scrutinized to ensure their validity. Feedback from the Cameroon team greatly enriched the findings. A joint communique on the research outcomes was produced with the visiting Cameroon team. The entire project adhered to strict ethical procedures. Participation was voluntary, and, at the participants' request, careful consideration and treatment of interview responses that could reveal identity were made anonymous. Hence, transcription of the interview sessions concealed the names and any other identifiable information about the interviewees.

Analysis of the data was informed by the full version of grounded theory (Henwood and Pidgeon 2006). The data collected from Cameroon were transcribed, anonymized, coded, and subjected to constant comparative analysis to establish linkages between relevant themes. The executive briefing, where preliminary findings were presented, served as an opportunity to broaden and refine the analysis-further sought and clarified manifestations of categories, subcategories, or emerging themes in the data. Furthermore, triangulation of different data sources was done in a mostly qualitative analysis, although basic quantitative statistical analysis has been embedded within them (Charmaz 2006). The structure of the findings (categories and subcategories) was derived from interview themes that are consistent with responses, and also with new themes that emerged from coding comparative analysis of primary information sources.

\section{Why Disaster Risk Reduction and Resilience Are Important to Cameroon}

Cameroon's risk profile is firmly linked to its vulnerable population, which is exposed to natural, potentially socionatural, technological, and social and anthropogenic hazards (Bang 2016; Table 1; Fig. 3), making risk reduction and resilience imperative.

The main natural hazards in Cameroon are volcanic eruptions, earthquakes, landslides, and toxic gas emissions from crater lakes associated to the Cameroon Volcanic 
Fig. 3 Cameroon map showing locations of the main hazards in the country Source Authors

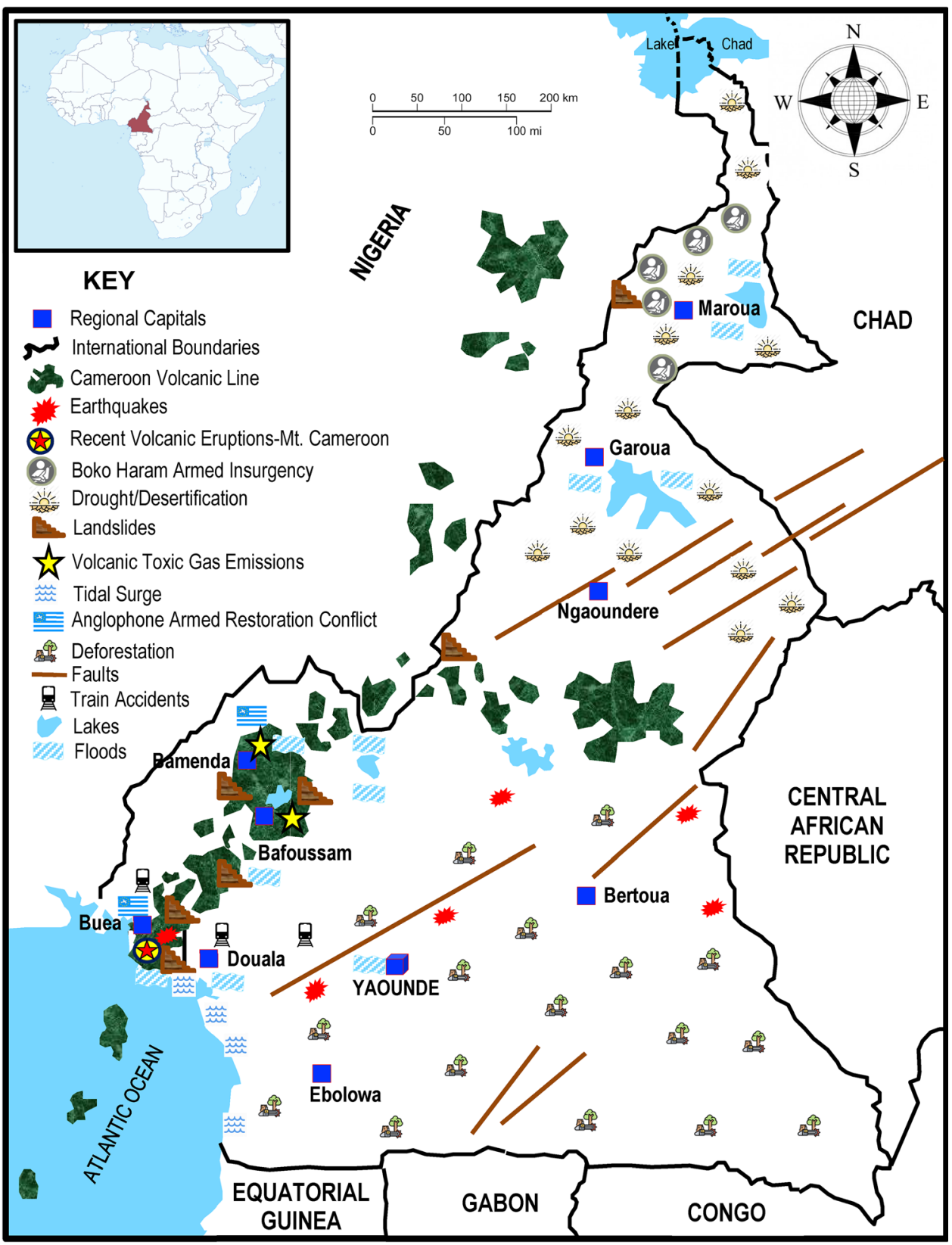

Line (CVL) - a series of volcanoes that straddles the Gulf of Guinea and extends for over $1600 \mathrm{~km}$ in the country. Mount Cameroon is the highest and most active volcano in West and Central Africa whose eruptions (eight times in the twentieth century) are associated with earthquakes, which also pose a threat to population centers in the region (Favalli et al. 2012). If an earthquake occurs in the tectonically active seismic zone in the South Region, there is a risk that it can generate a tsunami that will affect the coastal region around Kribi (Fogwe 2010). Earthquakes also trigger landslides, which can also cause lahars/volcanic mudflows especially on the flanks of the CVL during heavy downpours. The CVL also hosts dangerous crater lakes. In 1984 and 1986 poisonous gases from Lakes Monoum and Nyos killed 37 and 1746 people respectively (Fogwe 2010; Bang 2016). Figure 3 shows the location of the main hazards in Cameroon.

Meteorological hazards like thunderstorms are often accompanied with very strong winds, heavy rain, and lightning that affect many parts of the country, especially during the rainy season, damaging physical capital (Fogwe 2010). The storms also cause flash floods, exacerbated by the mountainous nature of the CVL. Statistics from the emergency events database (EM-DAT) reveal that from 1990 to 2014, floods had the highest frequency of occurrence $(77.7 \%)$ of all natural hazards in Cameroon, followed 
by drought (16.7\%), and landslides (5.6\%) (CRED 2018). And during this period, $85.9 \%$ and $14.1 \%$ of the mortality was from floods and landslides, respectively. In 2012, the worst flooding in Cameroon in over 60 years hit northern Cameroon with devastating consequences. The floods caused the greatest number of fatalities (more than 30 deaths, about 3000 hospitalized, more than 60,000 displaced), property and infrastructure damage, and disruption of services throughout the region in more than three decades (Bang 2016; Bang et al. 2018, 2019).

Flooding often led to a rise in waterborne diseases and health hazards such as dysentery, malaria, diarrhoea, catarrh, and cough. The situation is worsened by frequent epidemics (cholera, measles, and meningitis) in many parts of the country (Table 1). Other biological hazards like locust infestations and elephant-caused crop destruction are also a threat to agricultural production (FAO 2016; Bang et al. 2018). These hazards have dire consequences for livelihoods, including food security, and are exacerbated by the difficult socioeconomic challenges in the country.

Cameroon's DM system is also struggling to manage technological disasters, which are becoming more prominent in the country. According to CRED (2018), from 1988 to 2018,41 technological disasters occurred in Cameroon. These events resulted in 1542 fatalities, 1272 injuries, and affected 3061 people. Analysis using the EM-DAT database shows that of all transportation accidents, rail crashes cause the highest number of injuries and are second to fire hazards in terms of the total number of people affected in all technological disasters in the country.

Anthropogenic hazards in Cameroon are dominated by an increase in conflict due to the regional Boko Haram insurgency and the Ambazonian conflict. Since 2017, Cameroon's anglophone regions have become the primary political concern for the government due to the Ambazonian crisis, which has escalated into an armed conflict. Violent clashes between the armed separatist fighters and the Cameroon security forces have caused the deaths of several hundred innocent civilians, separatist fighters, as well as security forces. In addition, thousands of Cameroonians in the North and South West Regions have fled over the border into Nigeria or relocated to other towns in the country. According to a recent report by the United National High Commission for Refugees (UNHCR), the conflict has led to 437,000 internally displaced persons (IDPs) and 35,000 Cameroonian refugees in Nigeria (UNHCR 2019).

Additionally, urbanization is increasing the susceptibility of population centers to natural hazards especially those in the Mt Cameroon region, which are at risk of lava flow inundation, landslides, and flash floods (Favalli et al. 2012). Social vulnerabilities in the country are linked to economic deprivation, deficient infrastructures, prevalence of endemic diseases, and low educational attainment in many areas. This often causes devastating impacts to the populations subjected to such shocks, which result in deaths, the displacement of people, damage to agricultural produce and rural livelihoods, and the destruction of physical and social infrastructure (Bang et al. 2018). Despite the high risk of hazards in the country, the authorities have been unable to learn, enhance, and engage effective DRR strategies (Miles et al. 2017).

\section{Research Findings}

Building on the identification of resistance factors outlined in Sect. 2, the findings suggest the existence of a number of resistance factors to achieving DRR in Cameroon that cumulatively represent a major challenge. These barriers undermine the implementation and effectiveness of DRR/ DM in the country. The following resistance factors were identified.

\subsection{Resistance in Communication}

The research identified two main types of resistance in communication: weak precrisis early warning system communication and weak intelligence on early warning communication.

\subsubsection{Weak Precrisis Early Warning System Communication}

All respondents (100\%) said precrisis disaster communication is very weak. Some mentioned the lack of adequate structures at the local and regional levels to continuously educate or sensitize "at risk" populations about risk reduction measures, including about impending risks and possible disasters. One notable reason given in the interviews was the ongoing challenge of disseminating information in several local languages in order to reach the substantial diversity of ethnic groups in the country.

Respondents also emphasized that scientific early warning systems are very weak or limited. Responses indicate lack of consistency in monitoring risk zones, such as the volcanically active Mt. Cameroon region, due to poor, even complete lack of, maintenance of faulty monitoring equipment. In fact, several respondents cited how the 1999 eruption of Mt. Cameroon had especially taken everyone by surprise largely because of inoperative equipment (interviewees; Miles et al. 2017). Eighty percent of the respondents cited the devastating 2012 floods in Northern Cameroon where the hydrological regimes of the rivers in the region were not monitored, although the region experiences annual flooding (Bang et al. 2019). 
These examples have clear implications for the level of integration of data gathering, monitoring, and intelligence information available for DRR and crisis planning.

\subsubsection{Weak Intelligence on Early Warning Communication}

The research was also informed (60\% of interviewees) that although the bottom-up reporting of any impending risks is expected to follow protocol, top-down confidence in the quality and accuracy of any information provided from bottom-up sources is very weak and often causes delays. This is particularly true with early warning information about imminent risks, which is passed upwards through the hierarchy to inform decision making and action but is often ignored. Eighty percent of the respondents complained that reports or information on imminent risks underwent a wasteful time-consuming process of vetting, cross checking, and verification to ensure "accuracy." One respondent quipped: "the authorities have failed to realize that scientific risk assessment and early warning is not $100 \%$ certain but based on probability." Interview transcripts also reveal that disaster predictions are a double-edged sword. If the anticipated disaster fails to occur, precautions, preparations, and evacuations that have been taken are regarded as wasteful and ill-informed. Those responsible are vilified, regarded as incompetent, and may not be taken seriously again in subsequent periods of high hazard risk. As a result, scientists fear to provide information on impending risks for fear of being ostracized if their predictions are not completely accurate. Thus, an additional form of communication resistance exists, which pertains to levels of confidence and lack of assurance in the quality and accuracy of crisis communication in place. This scepticism fosters resistance in terms of inertia and delay in handling and processing crisis communications. This lag time in response may have important implications in shaping the speed and direction of disaster outcomes.

Of the three communication deficiencies revealed by our investigation, weak precrisis early warning communication seems to be the most entrenched (Fig. 4).

\subsubsection{Administrative Bottlenecks in Crisis Communication}

There is evidence that even in precrisis and crisis situations, bottom-up communication with and among disaster managers is not straightforward. Information goes through a long evaluation process, and is also hampered by administrative bottlenecks and complicated reporting procedures. According to $70 \%$ of the interviewees, this arises because Cameroon's DM legislation has no guidelines for stakeholder involvement, especially for scientists who should be monitoring and interpreting imminent risks. Respondents also mentioned that most official government documents and communications are in the French language. This practice is in contradiction to official government policy that requires such documents and communication to be available in both English and French. According to the respondents (60\%), this has implications for prompt communication for English-speaking DM technocrats. Consequently, there are delays in key decisions and actions. There is another form of "communication resistance" in existence that stems from weaknesses in the coordination and integration of stakeholders within key communication flows that are essential if delays and inertia are to be avoided. Without speedy decisions, DM cannot be undertaken that may eventually save lives, reduce casualties, and limit infrastructural damage.

\subsection{Resistance in Decision Making}

One of the ways in which delays in decision making occur - that was regularly cited among respondents-relates to the desire for disaster managers to conform exactly and prescriptively to guidelines or written instructions on what actions to take before and during a crisis situation. Put succinctly by one respondent, "what does the text say?" This is obviously a good thing in many respects; but for the fact-as another respondent highlighted-that the DM legislation is narrow, not explicit, and lacks clarity on responsibilities. Further responses alleged that while some disaster managers at the national level have basic knowledge of DM legislation, those at the regional and local levels are not very knowledgeable about or fully understand "what the text says." Several reasons for this were cited. These include that local disaster managers did not have access to the respective texts, have not been empowered to understand the legislation, or simply did not bother to find out. At best, these tendencies represent the prevalence of top-down, hierarchical, and differential organizational behavior, adapted to and based on a highly legal-bound and document-based decision-making culture in DM.

\subsection{Resistance in the Coordination of Disaster Risk Reduction Activities}

Findings also reveal that prior to crises or disasters, intersectorial coordination between DM agencies at the national, regional, and local levels is minimal. Senior disaster managers indicated that supportive agencies and ministries to Cameroon's DCP also rarely organize risk reduction related preparatory activities. Indeed, stakeholder agencies are requested to help mostly during crisis situations. At that moment, they struggle to provide their services because there have not been sufficient preparatory time and simulation exercises allocated to crisis planning. 
Fig. 4 Percentage of interviewee responses to types of deficiencies in communication. $E W$ Early warning

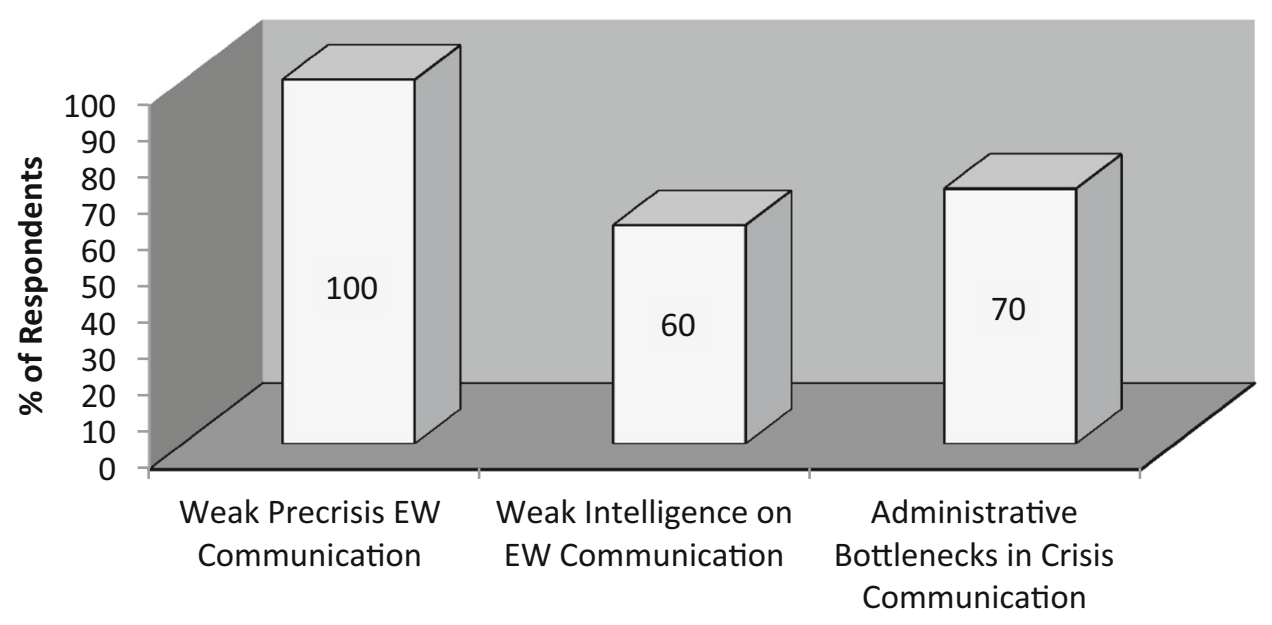

Communication Deficiency Types
In these circumstances, agencies redefine their role to suit what they can offer, and not what they ought to offer. Agencies concerned with risk monitoring and assessment, logistics, and relief and rescue services fall within this bracket. A senior disaster manager, for example, mentioned specifically that officials' adherence to key texts also meant a corresponding restriction on the encouragement, level, and intensity of intersectorial cooperation. This was especially relevant in cases where DM planning documents, plans, and texts did not specifically stipulate in what form such cooperation should take place, demonstrating notable instances of inertia (resistance).

\subsection{Resistance in the Provision of Resources}

Findings on resistance in the provision of resources fall into three categories: insufficient human capital resources, insufficient financial resources, and insufficient material resources. The structural provision for disaster managers is not sustainable. All the respondents (100\%) highlighted the problem of lack of professionally trained disaster managers at all levels of the DM system. "Skilled disaster managers who can make strategic policies and plans on DRR in the country are not available," opined a senior disaster manager. In reality, government administrators at the national, regional, and local levels (ministers, governors, divisional officers), who double as disaster managers (albeit without DM training) as well as other members drawn from diversified sectors of the society are all expected to assist during crises. A respondent further explained that such members, whose main jobs may be remote from DM, can be transferred to work in other regions of the country. As a result, the entire team may not be available when they are needed. They stressed that without disaster managers who can be deployed to work in particular locations on a permanent basis, probably based on their skills, and recruited and paid by the state, human resources for DM will always be lacking.

Transcribed interviews reveal key resistance factors exist around financial and budgetary aspects. In particular, that budgetary allocations for DRR and DM as a whole are not enshrined in legislation, are unavailable to cooperating DM agencies, and not even explicit within the operating budgetary provisions of the DCP. Seventy percent of the respondents highlighted that stakeholder ministries and agencies are reluctant to make any budgetary provision for DRR/DM because they do not consider disaster issues as part of their respective responsibilities. When a crisis occurs, the government pledges to provide financial support to the affected area, which in many instances is very limited, and many promises that involve huge funds are not kept. Because the DCP is not financially able to handle most crises, the presidency always intervenes to provide support. This lack of adequate financial resources heavily impacts disaster preparedness, and especially affects negatively on contingency planning for risk reduction, as the focus is more on crises management, when more resources are made available.

Findings also show that the provision of material resources for DRR is an issue. Respondents with technical DM knowledge and specialist responsibility criticized the lack of vital equipment needed for risk reduction activities. They mentioned that some key services lack the 4-wheel drive vehicles needed for fieldwork in remote areas. In some instances, the repair of equipment resources is also lacking. For example, a respondent said prior to the 1999 Mt. Cameroon eruption, many seismometers used to monitor Mt Cameroon were not functioning and had not been replaced. This includes other essential technical equipment required to take measurements for risk 
Fig. 5 Percentage of responses on resistance in the provision of human, financial, and material resources

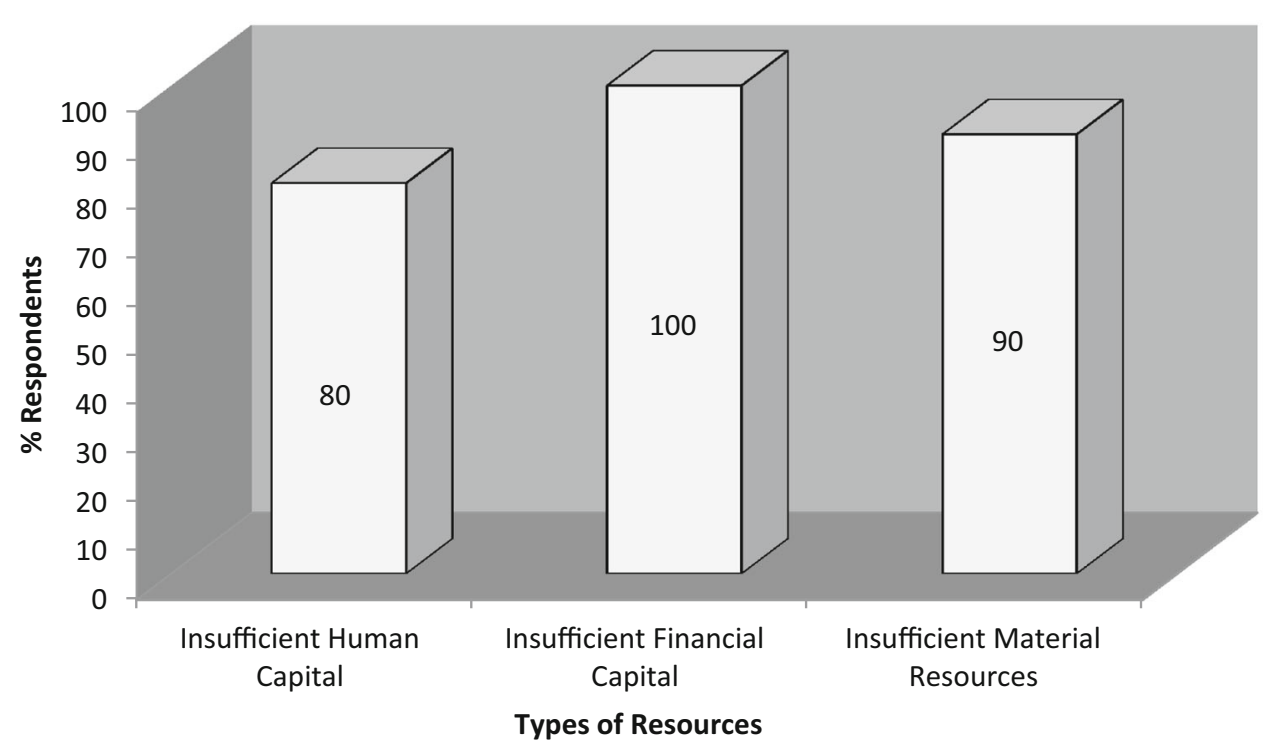

assessment. The research revealed that the few available resources are usually under pressure and if they have access to them, it is only for a short time. As a result, scientists are always never fully resourced to complete their work. This obviously has implications for the effectiveness of scientific monitoring and assessment of risks in the country.

A closer look at the three types of resistance to resources reveals that insufficient human and financial capital are exceedingly predominant in Cameroon's DM system (Fig. 5).

\subsection{Resistance in International Assistance}

Our research has unveiled major issues in relation to the ability of top government officials to handle international aid and disaster relief. Often national DM frameworks are unable to process large amounts of immediate relief assistance-they are unable to handle the potential for embezzlement and corruption by officials who have access to and their hands on major new sources of income coming from abroad. All respondents (100\%) expressed concerns that a substantial amount of foreign funds provided for DM and risk reduction purposes are often diverted for other uses. For example, after the 2012 floods that hit North Cameroon, the government obtained USD 108 million from the World Bank to repair damaged hydraulic infrastructures - the Lagdo and Maga Dams in the region (World Bank 2013). The funds were disbursed, but some respondents intimated issues of transparency and a lack of clarity existed as to how the resources were used (Bang et al. 2019). Furthermore, during the 1986 Lake Nyos disaster, the Cameroon government received foreign cash donations amounting to more than 1.5 billion FCFA (African Financial Community Franc; about USD $3,000,000$ ), and a substantial amount of it was embezzled (Bang 2016). This type of resistance results in a lack of compliance with and ineffective administration of such international assistance in line with the requirements of the international funders and agencies.

\subsection{Resistance in Formulating Disaster Risk Reduction Plans and Policies}

All respondents (100\%) struggled to identify a comprehensive DRR policy and plans for Cameroon. The informants said there is no strategic plan for DRR policy and civil protection in Cameroon. Isolated DRR instruments exist in a variety of texts, legislation, and guidelines in different government stakeholder ministries and in the private sector. These contemporary DM/DRR laws, legislation, decrees, and ministerial instructions are disasterdriven. For example, shortly after the 1986 Lake Nyos disaster (1746 people killed), the government enacted Law No. 86/016 of 6 December 1986-mentioned earlier in Sect. 2, reorganizing civil protection in Cameroon. Two years later in 1988, a train crash in the Nsam neighborhood of Cameroon's capital, Yaoundé killed several people when the petrol it was carrying ignited. This incident, known as the Nsam Fire Disaster, triggered Decree No. 98/031 of 9 March $1998^{2}$ to organize emergency management and major risk relief plans in the country, and also

\footnotetext{
${ }^{2}$ Decree No. 98/031 of 9 March 1998 (French) is about the organization of emergency plans for disasters or major risks. https:// www.camerlex.com/wp-content/uploads/2018/03/recueil-des-textesMINATD.pdf (pages 448-450). Accessed 21 December 2018.
} 
led to Decree No. 96/054 of 12 March $1996^{3}$ that established the National Council on Civil Protection (NCCP). Because the country subsequently experienced several minor to major fire incidents, this series of events provided the impetus for Law No. 2001/182 of 25 July 2001, ${ }^{4}$ reorganizing the National Fire Brigade (Sappeurs Pompiers) (MTAD 2011; Bang 2014). These examples show a lack of foresight in the formulation of DM/DRR legislation and plans.

\subsection{Resistance in Mainstreaming Disaster Risk Reduction into Sustainable Development Plans}

Respondents were very sceptical that Cameroon is mainstreaming DRR into development plans and policies. Cameroon has signed on to many international frameworks and actions that stipulate measures for DRR (Fig. 2). These include the 1994 Yokohama Strategy and Plan of Action for a Safer World; the 2000 Millennium Development Goals; the 2002 Johannesburg Declaration on Sustainable Development; the 2005 Hyogo Framework for Action 2005-2015; the 2007 Global Platform for Disaster Risk Reduction; the 2012 Sustainable Development Goals; the 2014 African Regional Platform for DRR; the International Civil Defence Organisation, and the SFDRR. At face value, the ratification of these international agreements indicates commitment for DRR and sustainable development. In reality, their implementation leaves much to be desired. Cameroon's Poverty Reduction Strategy Papers, Growth and Employment Strategy Papers, and Cameroon's Vision 2035 Strategy Plan all articulate risk reduction as a priority for government to promote development in the country. All respondents (100\%), however, expressed doubts about implementation, citing very little or no government commitment to actualise these DRR commitments.

Figure 6 is a graphical representation of how intense or entrenched the resistance factors that exist in Cameroon's DM system actually are when analyzed from the survey responses. As shown on the chart, the four most important are the provision of resources, mainstreaming DRR into sustainable development, formulating DRR plans and policies, and coordination of DRR activities.

\footnotetext{
${ }_{3}^{3}$ Decree No. 96/054 of 12 March 1996 established the composition and powers of the National Council on Civil Protection. https://www. camerlex.com/wp-content/uploads/2018/03/recueil-des-textes-MIN ATD.pdf (pages 445-447). Accessed 21 Dec 2018.

${ }^{4}$ Law No. 2001/182 of 25 July 2001 reorganized the National Fire Brigade (French). https://www.osidimbea.cm/institutions/gouverne ment/sapeurs-pompiers/. Accessed 10 March 2018.
}

\section{Discussion}

The research presented in this article demonstrates that implementation of international disaster management frameworks that articulate DRR remains very limited. The SFDRR puts more pressure on African DM frameworks to ensure that DRR measures are implemented as effectively as possible. Yet planners still largely fail to consider resistance factors that impede DM in these resource poor countries where political, social, and cultural traditions and norms are notably different. As a result, there is the propensity for resistance, situated in political, social, and cultural contexts that constitute formal and informal challenges to the implementation of effective DM strategies.

The detailed findings, which reveal that resistance to DRR is embedded and operating in time and space within the DM frames and systems in Cameroon, align with research on related themes (Becker et al. 2013, Adelelam and Asiyanbi 2016, Bang et al. 2018, World Bank 2018). We argue that resistance to contemporary DM systems in Africa is often due to wider political, cultural, social, and economic dimensions linked to development that influences many aspects of DRR governance. The findings can - albeit to a limited extent-be extrapolated to other African countries, raising the question whether universally accepted Western DM frameworks remain completely appropriate to or are fully applicable in African countries.

The findings have shown that Cameroon's legislative frame is disaster-driven, undermining DRR activities. The Hyogo Framework for Action stressed the importance of good legislation to support DRR. This was reiterated during the SFDRR (UNISDR 2015a). Cameroon is a signatory to these agreements, but does not comply. Indeed, if Cameroon and other high-risk African countries are to achieve sustainable development, its DM systems should have conscious foresight, mitigating negative drivers and risk through positive actions, albeit with consideration for its unique socio-political and cultural environment.

Findings on decision making exposed poor knowledge of DM legislation, with implications for both proactive and reactive DM governance measures. When a crisis strikes, disaster managers waste valuable time making enquiries about the right course of action. Since the "text" might not address all plausible situations in great detail and may not be very explicit (or is extremely vague in some instances), a lot of time is lost trying to seek advice or wait for instructions from the top level of the political hierarchy. This creates unnecessary delays and critical actions might be missed. This highlights a lack of the bureaucratic initiative and an absence of the entrepreneurial resilience required to solve emerging DM problems. 
Fig. 6 Percentage of responses on resistance factors in Cameroon's DM system. DRR Disaster risk reduction

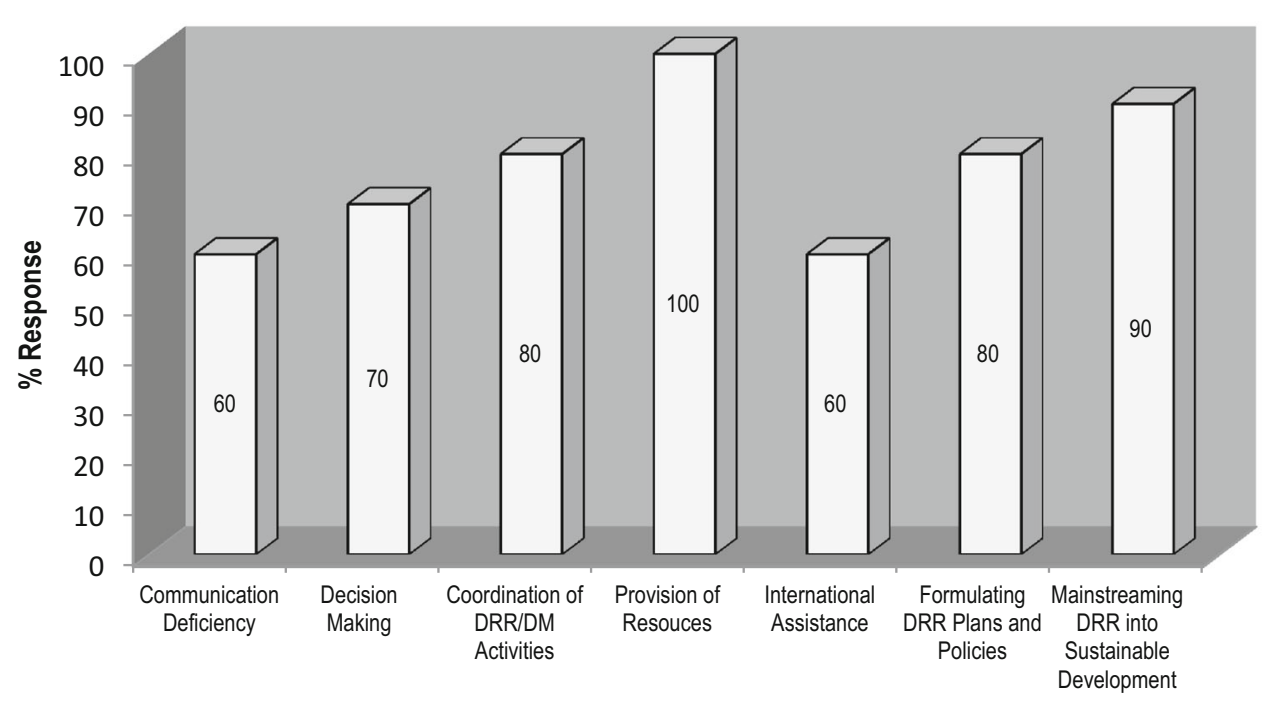

Resistance Factors
The findings also reveal weak DM and risk reduction communication systems. Cultural factors are partly to blame. Cameroon, like many African countries, has hundreds of different local languages. Coupled with a high illiteracy rate, communication with and education of local populations is a challenge. While the media can help create public awareness about risks and DRR interventions, their meager coverage and inability to translate the message into local languages limit the utility of media reportage in promoting effective public sensitization of DRR. With limited help on risk reduction from the state, the importance of community resilience has become even more apparent, as communities become even more reliant upon doing things for themselves.

The SFDRR stresses that national authorities should promote the cooperation of multiple stakeholders and diverse institutions at all levels, including affected communities and the private sector (UNISDR 2015a). Interestingly, the government acknowledges that in order to reduce disaster risk, numerous players at the local, regional, and national levels need to work together (MTAD/ DCP 2005). Interministerial, cross-sectorial, and multilevel cooperation are challenging, however, as this research has uncovered. What is unclear is how responsibility for DM is shared, and what level and degree of linkages and interaction between the different agencies is required (Bang 2014).

Our research also found that national funding of risk reduction activities is very minimal, a conclusion confirmed by the DM reports of the DCP (MTAD/DCP 2005). This can be attributed to Cameroon's economy and internal politics. Cameroon's weak economy has placed greater pressure on the government to handle not just increased frequency of disasters (Miles et al. 2017), but also urbanization, population growth and the constant demographic trends that substantially increase the degree of risk and the probabilities of loss of life. Van Niekerk et al. (2013) reported that direct investments in DRR in Africa remain low and spending on DRR as an aspect of national budgets is weak and inaccurate. Van Niekerk and his colleagues also attributed the main reason to not only the limited resources that many African governments have to invest in DRR, but often their lack of aptitude to disaggregate specific budgetary allocations to DRR. Foreign aid, therefore, becomes important for Africa's DRR activities.

Foreign aid has played a significant role in shaping Cameroon's DM landscape, although such aid also is subject to abuse. International assistance is essential at times of crisis and disasters and can also provide the muchneeded funds for DRR. Indeed, development aid packages often articulate the need to mainstream DM practices into development, with risk reduction becoming a central integrated activity. As such, identified resistance has always provided rationales for DM authorities in Cameroon to demonstrate that their DM frameworks and capacities have been overwhelmed and therefore require sizable international assistance. For example, much of the local and foreign cash donations to the Cameroon government following the 1986 Lake Nyos disaster that amounted to around 1.5 billion FCFA (about USD 3,000,000) were embezzled (Bang 2016). This highlights issues of inappropriate disbursement of foreign assistance after receipt (Bang et al. 2019). The identification of resistance factors also offers opportunities to use and rationalize the existence of resistance as an opportunity to improve resilience via the undertaking of new measures or attracting new resources for improving resilience. 
The political will to invest in risk reduction is in doubt. Cameroonian politicians prefer to respond to hazards with relief aid, which the population appreciates, rather than invest in risk aversion measures that are not very conspicuous. Therefore, political decisions associated with DM are exacerbating vulnerability to hazards. How successful African countries are in reducing their actual and potential rate of risks critically depends on the political leadership's commitment and ability to implement and enforce appropriate DRR measures (Van Nierkerk et al. 2013)

Our research results also reveal that Cameroon's DCP is powerless to coordinate across stakeholder ministries. The DCP is a directorate under the Ministry of Territorial Administration, and lacks the power, authority, and funding to perform any risk reduction functions; this matches findings from Bang (2014). The most successful DM institutions tend to be associated with order, power, control, and security, and therefore have substantial political and policy connotations (Hills 2000). Cameroon's DCP lacks these attributes.

Appropriate human resources required for effective DRR are lacking. While Cameroon has several research institutions with skilled researchers in various aspects of risk reduction, it lacks DM technocrats. Senior disaster managers are political appointees, usually without DM training and/or experience, who may be sacked, replaced, or transferred at any time. To enhance resilience, there is a need to be entrepreneurial in thinking and acting on resistance to DRR. Human capital plays a critical role in providing resilience to DM systems and processes. Such "gatekeepers" can act as innovators or policy entrepreneurs in DM (Miles 2016), with great potential to fill "resistance gaps." The identification of such gatekeepers in many African DM systems is very important, albeit beyond the scope of this article.

We argue that a peculiar DM culture in Cameroon is partly responsible for most of the identified resistance factors. There is generally a relaxed and unconventional manner of performing DM and other administrative functions. Although incorrect, this attitude is acceptable to many simply because that is how it has been done by others before. Without adequate monitoring and evaluation of DM activities, many wrong decisions become a norm. For example, the perception of DM in the country is erroneously synonymous to assisting disaster affected communities with relief aid. Interestingly, the government acknowledges difficulties in engaging in risk reduction activates due to the lack of a culture of prevention among the populace, and insufficient interest in civil protection in the private sector (MTAD/DCP 2005). We contend that the government is the architect of that culture. Yet African governments have been urged to create a culture of DRR at all levels, and to empower those at risk to achieve protection against disaster impacts (UNISDR 2013).

Another cultural issue peculiar to Cameroon is the country's bilingual nature. In principle, all official documents in Cameroon are translated into French and English-the two main official languages. In practice, however, most official documents are in French, which limits access to DM knowledge by the English-speaking populace. This has often led to noncompliance where community leaders and local people are not sufficiently informed of risk aversion measure due to a language barrier.

Based on the findings of this research, more robust discourse that addresses underlying risk drivers, promotes risk-sensitive development, and reforms risk governance in Africa is needed. We believe that understanding resistance to DRR is central to the development of effective disaster risk management at the local, regional, and national levels. That is why, regardless of efforts and ever-stronger commitments by many African governments and DM systems to enhance resilience, there remain major challenges influencing DRR implementation in developing economies. This research is important because deciphering resistance to DRR in Cameroon will enable resistance factors to achieve greater prominence as part of any search for resilience indicators. Table 2 is a summary of the identifiable resistance factors in Cameroon and recommendations on how to resolve these obstacles.

\section{Conclusion and Recommendation}

To a limited extent, the research presented in this article adds even greater weight to the need to further question and explore any (apparent) success of conventional DM frameworks in promoting DRR in developing countries. Using the case study of Cameroon, our research offers further insight into how understanding specific resistance factors in African countries could shape the basis of greater questioning in the future. In particular, this research has tested the hypothesis that the operational DM system in Cameroon is not in conformity with contemporary international DM frameworks. Based on the guiding DRR principles contained in the SFDRR to which Cameroon is a signatory, this article presented conceptual ideas on resistance factors and their implications for DRR in Cameroon.

Our findings reveal that there is clearly identifiable resistance in the DRR phase of Cameroon's DM system. These factors include resistance in communication; decision making; coordination of DRR activities; provision of resources; international assistance; formulation of DRR plans and policies, and incorporation of DRR into sustainable development plans. 
Table 2 Sendai Framework guidelines and their corresponding resistance elements/factors and suggestions for alleviating them

\begin{tabular}{|c|c|c|c|}
\hline $\begin{array}{l}\text { Sendai } \\
\text { framework } \\
\text { guidelines (see } \\
\text { Fig. 1) }\end{array}$ & $\begin{array}{l}\text { Corresponding } \\
\text { resistance elements in } \\
\text { Cameroon's DM } \\
\text { system }\end{array}$ & Resistance factors & $\begin{array}{l}\text { Alleviation of resistance factors or } \\
\text { recommendations }\end{array}$ \\
\hline \multirow[t]{5}{*}{9,10} & \multicolumn{3}{|c|}{ Deficiencies in communication } \\
\hline & $\begin{array}{l}\text { Weak precrisis early } \\
\text { warning (EW) } \\
\text { communication }\end{array}$ & $\begin{array}{l}\text { Lack of EW communication structures at } \\
\text { regional/local levels. Weak scientific EW } \\
\text { systems. Inconsistency in monitoring risk } \\
\text { zones }\end{array}$ & $\begin{array}{l}\text { Risk monitoring/EW systems to be enshrined in } \\
\text { legislation and backed by political will, } \\
\text { commitment, and provision of required } \\
\text { resources to scientists. Scientific research } \\
\text { institutes should be given responsibility for EW }\end{array}$ \\
\hline & \multirow[t]{2}{*}{$\begin{array}{l}\text { Weak intelligence on } \\
\text { EW communication }\end{array}$} & $\begin{array}{l}\text { EW intelligence goes through a wasteful time- } \\
\text { consuming administrative vetting process }\end{array}$ & $\begin{array}{l}\text { All EW intelligence should be expedited up the } \\
\text { decision-making process }\end{array}$ \\
\hline & & $\begin{array}{l}\text { Inaccuracy in EW information may cause those } \\
\text { concerned to be vilified }\end{array}$ & $\begin{array}{l}\text { More scientific technocrats should be appointed to } \\
\text { strategic DM positions }\end{array}$ \\
\hline & $\begin{array}{l}\text { Administrative } \\
\text { bottlenecks in crisis } \\
\text { communication }\end{array}$ & $\begin{array}{l}\text { Bottom-up communication goes through a long } \\
\text { chain of reporting process }\end{array}$ & $\begin{array}{l}\text { Bottom-up crisis communication should be } \\
\text { simplified with situational awareness easily } \\
\text { available to all DM stakeholders }\end{array}$ \\
\hline \multirow[t]{2}{*}{$6,7,9$} & \multirow[t]{2}{*}{ Decision making } & \multirow{2}{*}{$\begin{array}{l}\text { Desire to take decisions based on "the text," } \\
\text { which is not explicit. Regional/local disaster } \\
\text { managers less knowledgeable on DM issues }\end{array}$} & $\begin{array}{l}\text { Adequate DM plans should be produced that have } \\
\text { clear roles and responsibilities }\end{array}$ \\
\hline & & & $\begin{array}{l}\text { DM training programs should be rolled out to all } \\
\text { DM stakeholders at all levels }\end{array}$ \\
\hline $2,4,6$ & $\begin{array}{l}\text { Coordination of DRR/ } \\
\text { DM activities }\end{array}$ & $\begin{array}{l}\text { Pre-crisis intersectorial coordination for DRR is } \\
\text { minimal }\end{array}$ & $\begin{array}{l}\text { Regular national level stakeholder DM } \\
\text { coordination meetings should be organized }\end{array}$ \\
\hline \multirow[t]{7}{*}{10} & \multicolumn{3}{|l|}{ Provision of resources } \\
\hline & \multirow{2}{*}{$\begin{array}{l}\text { Insufficient human } \\
\text { capital }\end{array}$} & Lack of skilled disaster managers & \multirow{2}{*}{$\begin{array}{l}\text { There should be more professionally trained } \\
\text { disaster managers to work at all levels- } \\
\text { particularly strategic and operational levels }\end{array}$} \\
\hline & & Top disaster managers are political appointees & \\
\hline & \multirow{2}{*}{$\begin{array}{l}\text { Insufficient financial } \\
\text { resources }\end{array}$} & No legislative budgetary provisions for DRR & \multirow{2}{*}{$\begin{array}{l}\text { There should be budgetary provision for DRR in } \\
\text { all stakeholder ministries and agencies and } \\
\text { enshrined in legislation }\end{array}$} \\
\hline & & Insufficient funds for DRR & \\
\hline & \multirow[t]{2}{*}{$\begin{array}{l}\text { Insufficient material } \\
\text { resources }\end{array}$} & $\begin{array}{l}\text { Insufficient scientific DRR monitoring } \\
\text { equipment }\end{array}$ & \multirow[t]{2}{*}{$\begin{array}{l}\text { All required DRR equipment should be regularly } \\
\text { assessed, provided, and adequately maintained }\end{array}$} \\
\hline & & Delays in repairs of DRR equipment & \\
\hline \multirow[t]{3}{*}{10} & \multirow{3}{*}{$\begin{array}{l}\text { International } \\
\text { assistance (IA) }\end{array}$} & Embezzlement and corruption & \multirow{3}{*}{$\begin{array}{l}\text { There should be strict monitoring of international } \\
\text { assistance to prevent waste, embezzlement, and } \\
\text { diversion for other non-DM related purposes- } \\
\text { culprits should be punished to deter others }\end{array}$} \\
\hline & & $\begin{array}{l}\text { Disasters as bait for foreign funds serve as } \\
\text { disincentive for DRR }\end{array}$ & \\
\hline & & $\begin{array}{l}\text { International assistance for DM/DRR diverted } \\
\text { for other purposes. }\end{array}$ & \\
\hline $1,3,7,8$ & $\begin{array}{l}\text { Formulating DRR } \\
\text { plans and policies }\end{array}$ & $\begin{array}{l}\text { No comprehensive DRR/DM policies plans and } \\
\text { programs. DRR/DM legislation is disaster- } \\
\text { driven and lacks foresight }\end{array}$ & $\begin{array}{l}\text { The country should regularly update its DM } \\
\text { legislative framework to reflect contemporary } \\
\text { DM challenges and important DM foresights }\end{array}$ \\
\hline \multirow[t]{2}{*}{$1,3,4$} & \multirow{2}{*}{$\begin{array}{l}\text { Mainstreaming DRR } \\
\text { into sustainable } \\
\text { development (SD) }\end{array}$} & $\begin{array}{l}\text { Not sufficiently integrating DRR measures into } \\
\text { long-term development plans and programs }\end{array}$ & \multirow{2}{*}{$\begin{array}{l}\text { All development programs should identify } \\
\text { potential risks and inculcate risk reduction } \\
\text { measures in their implementation }\end{array}$} \\
\hline & & $\begin{array}{l}\text { Not complying to several international } \\
\text { agreements on DRR for sustainable } \\
\text { development }\end{array}$ & \\
\hline
\end{tabular}

$D M$ disaster management, $D R R$ disaster risk reduction

The various resistance factors identified are not surprising. They have been diagnosed in other African countries and often attributed to their operational political, economic, and sociocultural environment. By understanding and evaluating where in particular these resistance factors have resonance, their mitigation will avoid the need for generalized measures across an entire DM system. Comprehensive systems overhaul would prove expensive especially in the context of DM systems in developing countries where resources are already stretched. Targeted measures could include reform of procedures, honed reorganization of DM agencies, selective refining of 
communication strategies, and enhancement of wider stakeholders and community groups.

Understanding the nature, scale, and distribution of risks informs risk reduction interventions and also urban planning, public health, and other risk-sensitive development policies (Fraser et al. 2017). Although current practice places emphasis on protecting development gains through attempts at mitigating major disasters, resilient development approaches include efforts to increase political commitment for DRR; improve identification and assessment of disaster risks; enhance public awareness and governance of DRR and integrate DRR into emergency response management (UNISDR 2013); we also advocate a greater focus on everyday risks. To achieve those goals, we have suggested recommendations on how to mitigate the identified resistance factors (Table 2).

There is a long road ahead if Cameroon is to substantially enhance the resilience of its DM and DRR frameworks when there is probably a rather short time before the country will inevitably experience another major disaster.

Acknowledgements This research was conducted under the auspices of the AFRIGATE (Unlocking the Gateways to Building Resilience and Promoting Innovation in Disaster Management in West Africa) project, initiated and led by the Bournemouth University Disaster Management Centre (BUDMC). AFRIGATE was a collaborative, policy oriented, practitioner relevant, and research-informed project involving DM expertise from the BUDMC and the disaster/emergency management agencies of three West African countries including Cameroon. The BUDMC is grateful to the UK's Official Development Assistance (ODA)'s Newton Fund for funding the AFRIGATE project and Bournemouth University's Research Knowledge and Exchange Office (RKEO) for providing administrative support. We also thank Cameroon's disaster management agency for dedicated participation in the project.

Open Access This article is distributed under the terms of the Creative Commons Attribution 4.0 International License (http://crea tivecommons.org/licenses/by/4.0/), which permits unrestricted use, distribution, and reproduction in any medium, provided you give appropriate credit to the original author(s) and the source, provide a link to the Creative Commons license, and indicate if changes were made.

\section{References}

Adelekan, I., and A. Asiyanbi. 2016. Flood risk perception in floodaffected communities in Lagos, Nigeria. Natural Hazards 80(1): 445-469.

Adelekan, I., C. Johnson, M. Manda, B. Matyas, S. Mberu, M. Parnell, D. Pelling, D. Satterthwaite, and J. Vivekananda. 2015. Disaster risk and its reduction: An agenda for urban Africa. Development Planning Review 37(1): 33-43.

Ashu, R., and D. Van Niekerk. 2019. A status quo analysis of disaster risk reduction policy and legislation in Cameroon. Foresight 21(3): 362-376.

Bang, H. 2014. General overview of the disaster management framework in Cameroon. Disasters 38(3): 562-586.
Bang, H. 2016. 30 years after the Lake Nyos disaster: What prospects for rehabilitation and reintegration in the region? Disaster management, social vulnerability, risk perception and relocation decisions in Cameroon. Ishpeming, MI, USA: Book Venture Publishing.

Bang, H., L. Miles, and R. Gordon. 2018. Enhancing local livelihoods resilience and food security in the face of frequent flooding in Africa: A disaster management perspective. Journal of African Studies and Development 10(7): 85-100.

Bang, H., L. Miles, and R. Gordon. 2019. Evaluating local vulnerability and organisational resilience to frequent flooding in Africa: The case of Northern Cameroon. Foresight 21(2): 266-284.

Becker, P., M. Abrahamsson, and M. Hagelsteen. 2013. Parallel structures for disaster risk reduction and climate change adaptation in Southern Africa. Jàmbá: Journal of Disaster Risk Studies 5(2): 1-5.

Bhattacherjee, A. 2012. Social science research: Principles, methods, and principles, 2nd edn. Scotts Valley, CA: CreateSpace Independent Publishing Platform.

Charmaz, C. 2006. Constructing grounded theory: A practical guide through qualitative analysis. London: Sage.

CRED (Centre for Research on the Epidemiology of Disasters). 2018. The emergency events database. Brussels, Belgium: Centre for research on the epidemiology of disasters. http://www.emdat.be/. Accessed 30 Sept 2018.

Cresswell, W., and V. Plano Clark. 2011. Designing and conducting mixed method research, 2nd edn. Thousand Oaks, CA: Sage.

Etikan, I., A. Musa, and S. Alkassim. 2016. Comparison of convenience sampling and purposive sampling. American Journal of Theoretical and Applied Statistics 5(1): 1-4.

FAO (Food and Agriculture Organization). 2016. Increasing the resilience of agricultural livelihoods. http://www.fao.org/3/ai5615e.pdf. Accessed 12 May 2018.

Favalli, M., S. Tarquini, P. Papale, A. Fornaciai, and E. Boschi. 2012. Lava flow hazard and risk at Mt. Cameroon volcano. Bulletin of Volcanology 74(2): 423-439.

Fogwe, Z. 2010. Mitigating and managing regional geo-environmental hazards within a decentralisation transition in Cameroon. Journal of Human Ecology 30(3): 187-195.

Fraser, A., H. Leck, S. Parnell, and M. Pelling. 2017. Africa's urban risk and resilience. International Journal of Disaster Risk Reduction 26: 1-6.

Henwood, K., and N. Pidgeon. 2006. Grounded theory. In Research methods in psychology, 3rd edn, ed. G. Breakwell, S. Hammond, C. Fife-Shaw and J. Smith, 342-365. London: Sage.

Hills, A. 2000. Revisiting institutional resilience as a tool in crisis management. Journal of Contingencies and Crisis Management 8(2): 109-118.

Johnson, C., N. Toly, and H. Schroeder (eds.). 2015. The urban climate challenge: Rethinking the role of cities in the global climate regime. London: Routledge.

Miles, L. 2016. Entrepreneurial resilience. Crisis Response Journal 11(4): $52-54$.

Miles, L., R. Gordon, and H. Bang. 2017. Blaming active volcanoes or active volcanic blame? Volcanic crisis communication and blame management in the Cameroon. In Observing the volcano world, ed. C.J. Fearnley, D.K. Bird, K. Haynes, W.J. McGuire, and G. Jolly, 395-409. Cham: Springer.

MTAD (Ministry of Territorial Administration and Decentralisation). 2011. Compendium of legal texts. https://www.camerlex.com/ wp-content/uploads/2018/03/recueil-des-textes-MINATD.pdf. Accessed 13 Apr 2019.

MTAD/DCP (Ministry of Territorial Administration and Decentralisation/Directorate of Civil Protection). 2005. Risk prevention and disaster management in Cameroon. Contribution of civil 
protection in Cameroon to the Kobe Disaster Conference (Japan). Yaoundé: MTAD.

MTAD/DCP (Ministry of Territorial Administration and Decentralisation/Directorate of Civil Protection). 2009. Cameroon civil protection report, 2008/2009. Civil defence through life-saving actions. Yaoundé: MTAD.

Myers, G. 2011. African cities: Alternative visions of urban theory and practice. London: Zed Books.

UNHCR (United Nations High Commission for Refugees). 2019. Cameroon situation: Responding to the needs of IDPs and Cameroonian refugees in Nigeria. http://reporting.unhcr.org/ sites/default/files/UNHCR\%20Cameroon\%202019\%20Supple mentary\%20Appeal\%20\%28March\%202019\%29.pdf. Accessed 16 Jun 2019.

UNISDR (United Nations International Strategy for Disaster Risk Reduction). 2013. 4th Africa regional platform for disaster risk reduction, 13-15 February, Arusha, Tanzania. https://www. preventionweb.net/files/30143_4thafrpsummarystatement.pdf. Accessed 24 Jan 2019.

UNISDR (United Nations International Strategy for Disaster Risk Reduction). 2015a. Sendai framework for disaster risk reduction
2015-2030. http://www.unisdr.org/files/43291_sendaiframework fordrren.pdf. Accessed 14 Jan 2019.

UNISDR (United Nations International Strategy for Disaster Risk Reduction). 2015b. Disaster risk reduction in Africa. Status report. https://www.unisdr.org/files/51078_drrinafricaexecsum mary2015.pdf. Accessed 16 Jan 2019.

UNISDR (United Nations International Strategy for Disaster Risk Reduction). 2017. Sustainable development: Risk reduction. Report of the open-ended intergovernmental expert working group on indicators and terminology relating to disaster risk reduction, UN A/71/644,16-21184 (E). https://reliefweb.int/sites/ reliefweb.int/files/resources/50683_oiewgreportenglish.pdf. Accessed 10 Jun 2019.

Van Niekerk, D., C. Coetzee, C. Becker, L. Hildebrandt, K. Fourie, E. Annandale, B. Shoroma, E. Snyman, et al. 2013. Disaster risk reduction investments in Africa. Nairobi: UNISDR.

World Bank. 2013. Cameroon-flood emergency project. http:// documents.worldbank.org/ curated/en/449341468232165276/ Cameroon-Flood-Emergency-Project. Accessed 14 May 2017.

World Bank. 2018. Disaster management in Africa. https://www. worldbank.org/en/topic/disasterriskmanagement/overview\#2. Accessed 23 Dec 2018. 